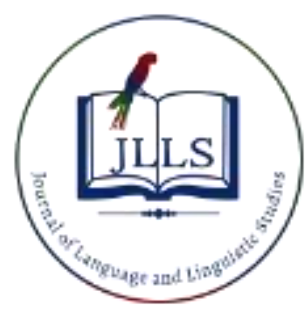

Available online at www.jlls.org

JOURNAL OF LANGUAGE

AND LINGUISTIC STUDIES

ISSN: 1305-578X

Journal of Language and Linguistic Studies, 16(2), 835-848; 2020

\title{
Comparison of student attitudes towards printed and digital dictionary use: \\ A case of middle school
}

\author{
Aslı Maden a 1 (iD) \\ APA Citation: \\ ${ }^{a}$ Giresun University, Giresun, Turkey \\ Maden, A. (2020). Comparison of student attitudes towards printed and digital dictionary use: A case of middle school. Journal of Language \\ and Linguistic Studies, 16(2), 835-848. \\ Submission Date:08/01/2020 \\ Acceptance Date:19/04/2020
}

\begin{abstract}
The present study aimed to compare the attitudes of middle school students towards printed and digital dictionary use. The study was conducted with the survey model since it aimed to determine a present situation. The study population included the students attending a middle school in Giresun province urban center during the 2018-2019 academic year. The sample that represented the study population was randomly selected $(\mathrm{n}=204)$ among the students attending a middle school in city center. The study data were collected with information form and attitude scales. The study findings demonstrated that the general attitudes of the students towards printed dictionary use $(X=2.54 / 4.00)$ and digital dictionary use $(X=2.76 / 4.00)$ were good. Furthermore, it was determined that gender did not have a significant effect on dictionary use attitude. The most important study findings included the improvement of student attitudes towards dictionary use with the increase in grade level, and the dictionary use attitudes of the students who started to use printed dictionaries during primary school or before were higher when compared to other students. However, the attitude towards digital dictionary use was observed as a developing attitude.
\end{abstract}

(C) 2020 JLLS and the Authors - Published by JLLS.

Keywords: Dictionary; printed; digital; vocabulary; use; attitude.

\section{Introduction}

It is necessary to know the words required to convey the emotions and thoughts completely and use these words accurately. In order to use the words as mentioned above, the individual's vocabulary should be rich, and it is necessary to have the habit of using a dictionary to achieve this.

Words are the smallest meaningful building blocks in a language, and dictionaries are the reference works that contain these meaningful building blocks. Dictionary is the general name of the works that include all or part of the words in one or more languages for general or special purposes, and provide the meaning, explanation and examples of these words that are mostly organized alphabetically (Ilhan, 2009, p. 535). In Turkish Dictionary (Turkish Language Institution [TDK], 2011, p. XI), the word

\footnotetext{
${ }^{1}$ Corresponding author. Tel.: +90-454-310-1012

E-mail address: asli.maden@giresun.edu.tr
} 
dictionary is defined as a reference book that records and explains the words of a language in all times or in a certain period, including their spelling, types, pronunciations, primary meanings and connotations, provides literary examples and reports the origins of adapted words. Based on the abovementioned definitions, words could be described as the carrier and protector of a language. In fact, to recognize the realm of meanings in a language, it is necessary to recognize the words and to investigate the properties of meaning and use of the words to measure the depth of a language. Thus, dictionaries are important for the existence of a language and its use as a means of communication, culture and thought. Students and individuals should utilize dictionaries accurately in order to use words correctly and accurately, thus improving their vocabulary.

Vocabulary instruction and development is a topic that should be initiated in preschool age and developed through sample texts based on developmental attributes and requirements of the child in school age. However, the development of vocabulary and accurate and proper use of the words depend on the acquisition of dictionary use skill by the student and transformation of this skill into a habit. In fact, the children should be instructed about the function of the dictionary, how to use a dictionary, and how it could be used as a reference book in daily life starting from the primary school age. Furthermore, the students should acquire the skills to use dictionaries in different levels of the education process and in extracurricular activities during the instruction new words and when demonstrating semantics, utilization, and etymology.

The students are required to use a dictionary to improve their vocabulary based on developmental attributes and requirements while developing their language skills. For this purpose, dictionary use habits of the students should be developed in native language education. Thus, after the basic information about dictionary use is provided for the students, how to find a word in a dictionary should be instructed and the students should be required to bring a dictionary to the classroom (Gocer, 2009, p.1039). Therefore, students who know and want to dictionary use, could use the dictionary more willingly and actively (Ahmed et al., 2018). This must be considered in order to students benefit from dictionaries more efficiently.

These instructions should be accompanied by examples. To provide these exercises in a certain order in the Turkish language course, various achievements and explanations were included in the curriculum. In the Turkish Language Course Curriculum (2018) is planed the students to recognize and use the dictionary section of reading material, to estimate and compare the meanings of the words they did not know when they read and listen, to develop a dictionary with new words. Thus, in the elementary and middle school language instruction, the students learn how to use the dictionary to improve their vocabulary and how to use the words correctly in the process of comprehension and utilization of the vocabulary, and the exercises that could be repeated for long periods could transform this knowledge into a habit.

Acquisition of the skill of dictionary use in Turkish language instruction and its transformation into a habit was determined as an achievement goal starting from the primary 2nd grade. Vocabulary learning activities in the textbooks suggest dictionary use. Reports on dictionary use habits indicated that the goals set in the curriculum were adopted. Several studies in the literature with Turkish dictionary use reported this development. For example, in a study by Yaman (2010) that investigated the Turkish dictionary use habits of elementary school students, it was reported that most students (81\%) a dictionary use when they an unknown word. In a study conducted by Melanloglu (2013) on middle school students, it was observed that students referred to the dictionary in both mother and foreign language courses. Also, Ibe Akcan (2015) conducted a study on students in foreign language departments in a university and the study findings revealed that the students had the habit of dictionary use. The digital dictionaries introduced by technological advances also affected the dictionary use habits of the students. TDK Contemporary Turkish Dictionary (URL-1), Oxford English Dictionary (URL-2), Longman Dictionary 
of Contemporary English (URL-3), Cambridge Dictionary (URL-4) are some of the digital dictionaries that are used extensively today. Aslan (2010) also found that university students often used mobile dictionaries to learn vocabulary. In fact, in a study by Dagtas (2014) on electronic dictionary utilization habits of secondary school students, it was concluded that students used digital dictionaries more than printed dictionaries due to features such as rapid access, ease of use and advanced vocabulary.

The fact that the students and teachers use the dictionaries at a certain level may not be sufficient to turn this skill into a habit. The referral to a dictionary due to the course requirements demonstrates that the act might not be repeated after the requirement is met. It is also necessary to instruct the students how to use a correct dictionary and how to check the information in the dictionary using various resources (Nesi \& Haill, 2002). In fact, in a study where Baskın (2017) investigated the dictionary needs of middle school students, it was determined that the school dictionaries did not meet student expectations such as organizing words and heteronyms alphabetically and holistically, providing the meaning, type, synonyms and antonyms, secondary, simile and terminological meanings, connotations and examples of segmental words. Thus, school dictionaries should be authored with care and based on the principles and requirements set forth in relevant studies.

Introduction of the dictionary to students as a reference book in primary and secondary education, how to find the meaning of a word and explanation of the functions of the word types could serve to transform the dictionary use skill into a lifelong habit. Furthermore, the interest of the students in dictionary use and development of a positive attitude towards dictionaries should be included in educational goals. It was also reported that users who were not trained in dictionary use could not utilize these resources actively and utilize the dictionaries only to look up the meaning of specific words when needed (Cowie, 1999; Ayoub, Mehmood \& Awan, 2017). Development of a positive attitude towards dictionary use would be decisive in benefiting from this resource. According to Allport (1967, p.8), attitude is an emotional and cognitive preparation process that is a product of experiences and with a determinative and dynamic effect on individuals' behavior towards all associated objects and phenomena (Cited by Can \& Deniz, 2016, p.324). In the Turkish Dictionary (TDK, 2011, p.2014), it was defined as the "adopted path and demeanor". Dictionary use also directly affects the development of student vocabulary, and thus effective use of language skills. Therefore, it is important to note that students should adopt a positive attitude towards dictionary use and enjoy using this resource. The acquisition of this skill is based on the fact that the student can easily find a word when referred to the dictionary. Also, the student should be kept clear of the prejudice that it would be difficult to carry the dictionary around and could not be used at all locations and the students should be directed towards easy-to-carry dictionaries. Thus, the use of dictionaries relevant to the student level in courses, guiding the students to acquire these dictionaries, the instruction on how to use the dictionaries by the teacher at the beginning, suggesting that dictionaries have other benefits such as spelling and etymological information in addition to word meanings, and the utilization of printed dictionaries as well as digital dictionaries in vocabulary activities would support the development of positive attitudes towards these resources. Therefore, digital learning has become an important educational and social model in the world of today. Students also use digital tools effectively to conduct research, learn, communicate, and share information (Karal et al., 2015; Ozdamar Keskin et al., 2015). On the topic, the studies where Yaman and Dagtas (2014) investigated the attitudes of 6th, 7th and 8th grade students and Can and Deniz (2016) investigated the attitudes of middle school students towards Turkish dictionaries are prominent. Furthermore, Ozbay and Melanlığlu (2013) and Kardas (2016) investigated the attitudes of students learning Turkish as a foreign language towards dictionary use, and certain other studies aimed to investigate the attitudes towards dictionary use within the concept of habit in the literature (Boz \& Demirtas, 2011; Ibe Akcan, 2015; Yaman, 2010 etc.). However, there was no previous study that analyzed the attitudes towards printed and digital or electronic dictionary use. Thus, it was considered 
that the studies on the attitudes of middle school students towards dictionary use were limited and studies on the topic would provide a basis for new regulations in the field.

\subsection{Research questions}

Based on the above-mentioned factors, the present study aimed to compare the attitudes of middle school students towards printed and digital Turkish dictionary use. For this purpose, the effects of various variables such as gender, grade level, and the age of initial dictionary use on these attitudes were determined.

Thus, the following research problems were determined based on the aim of the present study:

1. What is the level of the attitudes of middle school students towards printed dictionary use?

2. What is the level of the attitudes of middle school students towards digital dictionary use?

3. What is the correlation between secondary school students' attitudes towards printed and digital dictionary use?

\section{Methodology}

\subsection{Research Model}

The present study, which aimed to compare the attitudes of middle school students towards printed and digital dictionary use, was conducted with the survey method, a quantitative research model. The survey method aims to describe or explain characteristics of a group or groups such as societies, things, institutions, and events (Cohen, Manion \& Morrison, 2007; McMillian \& Schumacher, 2001).

\subsection{Sample}

The study population included the students attending a middle school in Giresun province urban center during the 2018-2019 academic year. The sample that represented the study population was determined with random sampling method. The sample included 204 students attending a middle school in Giresun province urban center.

The reason for choosing the sample from middle school students is that students to recognize dictionaries as a source of information and gain the ability dictionary use in the primary school period. Also in middle school, it is expected to turn this skill into a habit. In the Turkish Lesson Curriculum, it is important in this respect to turn this skill into a habit with the acquisition of a dictionary use skills from the 2nd grade, using different types of dictionaries in middle school and creating a dictionary. Thus, investigated of the attitudes of middle school students towards mother and foreign language dictionary use could prevent the problems that could be experienced in this transformation process. To find out the printed or digital dictionary use attitudes, a sample that included middle school students was selected.

\subsection{Data Collection and Analysis}

In the present study that aimed to determine the attitudes of middle school students towards printed and digital dictionary use and to analyze these attitudes based on various variables, the study data were collected with Information Form and Attitudes Towards Printed and Digital Dictionary Use Scale.

The Information Form included short-answer questions that aimed to determine the student demographics associated with the study aim and sub-problems. The data on the attitudes towards 
dictionary use were collected with the Attitudes Towards Dictionary Use Scale, developed by the author based on similar scales in the literature (Gomleksiz, 2004; Gunbatar, 2014; Karahan, 2018; Yaman \& Dagtas, 2013). The scale was a 4-point likert-type scale (4. Always, 3. Usually 2. Occasionally 1. Never). In the development of the scale, initially, the available scales on reading books and other texts, and attitude scales associated with dictionaries were reviewed, and a question pool that included 22 items was developed. Draft items were reviewed by Turkish language education specialists $(n=2)$, an educational sciences specialist $(n=1)$ and Turkish language teachers $(n=3)$ to determine content validity. A pilot scheme was conducted with 50 students in middle school. Based on the data collected in the pilot scheme, it was determined that the internal consistency coefficient of the scale was 0.81 . The construct validity of the scale was tested with factor analysis, and the analysis revealed that the KMO value was 0.766 and Barlett value was 851.90 . After the content validity, reliability and factor analysis, 3 items (below 0.40) with low factor loads were removed and the final scale included 19 items. The items removed are related to dictionary types and words whose meaning in reading texts is unknown. Since there are other items in this content, the scope validity has not been impaired. This scale was organized based on the use of printed and digital dictionaries (in two sections of Attitude Scale for Digital Dictionary Use and Attitude Scale for Digital Dictionary Use). 2 items were modified; other items were prepared jointly for dictionary use. Sampling was applied twice. Data collection instruments were distributed to the students in the sample by the Turkish language teachers and the same teachers collected the completed forms. The data collected in the study were analyzed by SPSS 16.0 software based on the research and sub-problems and the findings were presented and interpreted using tables.

To grade the value intervals in the data collection instrument, the ranges were calculated with the n$1 / \mathrm{n}$ formula. In data analysis, mean student attitude scores were coded as High, Good, Moderate and Low. Based on the interval calculated by the formula ( 0.74 points in each interval), the score intervals that correspond to each code were divided into four equal sections as follows:

Table 1. Scale score intervals

\begin{tabular}{cccc}
\hline Options & Value & Code/Level & Interval \\
\hline Never & 1 & Low & $1.00-1.74$ \\
\hline Occasionally & 2 & Moderate & $1.75-2.49$ \\
\hline Usually & 3 & Good & $2.50-3.24$ \\
\hline Always & 4 & High & $3.25-4.00$ \\
\hline
\end{tabular}

In the analysis of the collected data, the arithmetic mean was used to analyze the mean attitude towards printed and digital dictionaries use; t-test was used to test the effects of gender and grade; oneway analysis of variance (ANOVA) was used to test the age of the initial dictionary use variables. Significance level was accepted as $0.05(\mathrm{p}<0.05)$.

\section{Results}

The results on the attitudes of middle school students towards printed and digital dictionary use is presented in tables based on the research sub-problems:

\subsection{The attitudes of middle school students towards printed dictionary use}


Table 2. The mean printed dictionary use attitude

\begin{tabular}{cccc}
\hline & N & Mean & Standard Deviation \\
\hline $\begin{array}{c}\text { Printed Dictionary Use } \\
\text { Attitude }\end{array}$ & 204 & 2.5362 & 0.45037 \\
\hline
\end{tabular}

In Table 2, it could be observed that the general mean attitude score of the middle school students towards printed dictionary use was 2.54 . The comparison of the mean printed dictionary use attitude score and the possible highest score in the scale (76) revealed that the mean attitude score corresponded to 48.19. Furthermore, it was determined that the attitudes of the students towards printed dictionary use were at the good level based on the scale intervals. This finding demonstrated that students developed a positive attitude towards printed dictionary use, however, there is still space for improvement.

\subsection{Analysis of printed dictionary use attitudes based on gender}

Table 3. Printed dictionary use attitudes based on gender

\begin{tabular}{ccccccc}
\hline & Gender & $\mathrm{N}$ & Mean & Sd & $\mathrm{t}$ & $\mathrm{p}$ \\
\hline $\begin{array}{c}\text { Printed } \\
\text { Dictionary Use } \\
\text { Attitude }\end{array}$ & Female & 114 & 2.4983 & .51635 & & \\
\cline { 2 - 5 } & Male & 90 & 2.5842 & .34635 & & 0.175 \\
\hline
\end{tabular}

In Table 3, it could be observed that there was no significant difference between the attitudes of students towards printed dictionary use based on the gender variable $(t=1.355, p>0.05)$. It was observed that male students had higher attitude towards printed dictionary use scores when compared to that of the female students. However, this finding revealed that gender had no effect on student attitudes towards printed dictionary use.

\subsection{Analysis of printed dictionary use attitudes based on student grade level}

Table 4. Printed dictionary use attitudes based on student grade level

\begin{tabular}{ccccccc}
\hline & Grade & $\mathrm{N}$ & Mean & Sd & $\mathrm{F}_{(3,200)}$ & $\mathrm{p}$ \\
\hline \multirow{2}{*}{$\begin{array}{c}\text { Printed } \\
\text { Dictionary Use } \\
\text { Attitude }\end{array}$} & 5th Grade & 52 & 2.4831 & .37314 \\
\cline { 2 - 5 } & 6th Grade & 49 & 2.4640 & .52496 & & \\
\cline { 2 - 5 } & 7th Grade & 50 & 2.5484 & .40575 & & \\
\cline { 2 - 5 } & 8th Grade & 53 & 2.6435 & .47555 & & \\
\hline
\end{tabular}

In Table 4, it could be observed that the mean attitude score of the students towards printed dictionary use was $X=2.48$ in the 5 th grade, $X=2.46$ in the 6 th grade, $X=2.55$ in the 7 th grade and $X=2.64$ in the 8th grade. Thus, student attitudes towards printed dictionary use increased with their grade levels. The same increase was not observed in the 6th grade. On the other hand, it was determined that there was no significant difference between the mean attitude towards printed dictionary use scores based on the student grade level $(\mathrm{F}=1.692, \mathrm{p}>0.05)$. This finding demonstrated that the attitudes of the students towards printed dictionary use increased as their class level increased; however, the increase was not 
sufficient. Based on this finding, it can be suggested that the knowledge and experience acquired by the students on printed dictionary use in Turkish language courses at middle school level were not sufficient to create positive attitudes.

The Post-Hoc LSD test was conducted to observe the impact of student grade level on attitudes towards printed dictionary use in detail, and the findings are presented in Table 6.

Table 5. Post-Hoc Student Grade Level Analysis

\begin{tabular}{|c|c|c|c|}
\hline $\begin{array}{l}\text { Grade Level } \\
\text { (I) }\end{array}$ & $\begin{array}{c}\text { Grade Level } \\
\qquad(\mathrm{J})\end{array}$ & $\begin{array}{c}\text { Mean Difference } \\
(\mathrm{I}-\mathrm{J})\end{array}$ & $\mathrm{p}$ \\
\hline \multirow[t]{3}{*}{5} & 6 & .01911 & .831 \\
\hline & 7 & -.06529 & .463 \\
\hline & 8 & -.16036 & .068 \\
\hline \multirow[t]{3}{*}{6} & 5 & -.01911 & .831 \\
\hline & 7 & -.08440 & .350 \\
\hline & 8 & $-.17948^{*}$ & .045 \\
\hline \multirow[t]{3}{*}{7} & 5 & .06529 & .463 \\
\hline & 6 & .08440 & .350 \\
\hline & 8 & -.09507 & .283 \\
\hline \multirow[t]{3}{*}{8} & 5 & .16036 & .068 \\
\hline & 6 & $.17948^{*}$ & .045 \\
\hline & 7 & .09507 & .283 \\
\hline
\end{tabular}

Based on the data presented in Table 5, it was determined that the student grade level has a certain impact on student attitudes towards printed dictionary use. Furthermore, the lowest mean attitude score was observed with the 6th grade students and the highest attitude score was observed with the 8th grade students. The analysis demonstrated that there was a significant difference between the attitudes of the 6th grades and those of the 8th graders towards dictionary use, favoring the 8th grade students $(p<0.05)$. This finding revealed that middle school education had a positive effect on student attitudes towards printed dictionary use.

\subsection{Analysis of printed dictionary use attitudes based on the age of initial dictionary use}

Table 6. Printed dictionary use attitudes based on the age of initial dictionary use

\begin{tabular}{|c|c|c|c|c|c|c|}
\hline & $\begin{array}{c}\text { Initial } \\
\text { Dictionary Use } \\
\text { Age }\end{array}$ & $\mathrm{N}$ & Mean & $\mathrm{Sd}$ & $\mathrm{F}_{(2,201)}$ & $\mathrm{p}$ \\
\hline \multirow{3}{*}{$\begin{array}{c}\text { Printed } \\
\text { Dictionary Use } \\
\text { Attitude }\end{array}$} & Preschool & 16 & 2.5000 & .35696 & \multirow{3}{*}{3.696} & \multirow{3}{*}{0.027} \\
\hline & Primary School & 158 & 2.5774 & .44353 & & \\
\hline & Middle School & 30 & 2.3386 & .48841 & & \\
\hline
\end{tabular}


In Table 6, it could be observed that the mean printed dictionary use attitude scores of the students who started to use dictionaries in primary school was $X=2.58$, that of the students who started to use dictionaries at preschool age was $\mathrm{X}=2.50$, and that of the students who started to use dictionaries in middle school was $X=2.33$. Thus, it was determined that the printed dictionary use attitudes of the students whose initial dictionary use age was older were higher. It was determined that the initial age of dictionary use led to a significant difference in the printed dictionary use attitude scores $(\mathrm{F}=3.696, \mathrm{p}$ $<0.05)$. This finding demonstrated that students who started to use dictionary earlier would better acquire dictionary use habits; thus, it would be easier for them to develop a positive attitude towards printed dictionary use.

\subsection{The attitudes of middle school students towards digital dictionary use}

Table 7. The mean digital dictionary use attitude

\begin{tabular}{cccc}
\hline & N & Mean & $\begin{array}{c}\text { Standard } \\
\text { Deviation }\end{array}$ \\
\hline $\begin{array}{c}\text { Digital } \\
\text { Dictionary Use Attitude }\end{array}$ & 204 & 2.7577 & 0.36316 \\
\hline
\end{tabular}

In Table 7, it could be observed that the general mean attitude score of the middle school students towards digital dictionary use was 2.76 . The comparison of the mean digital dictionary use attitude score and the possible highest score in the scale (76) revealed that the mean attitude score corresponded to 52.39. Furthermore, it was determined that the attitudes of the students towards digital dictionary use were at the good level based on the scale intervals. This finding demonstrated that students developed a positive attitude towards digital dictionary use.

\subsection{Analysis of digital dictionary use attitudes based on gender}

Table 8. Digital dictionary use attitudes based on gender

\begin{tabular}{ccccccc}
\hline & Gender & $\mathrm{N}$ & Mean & $\mathrm{Sd}$ & $\mathrm{t}$ & $\mathrm{p}$ \\
\hline $\begin{array}{c}\text { Digital } \\
\text { Dictionary } \\
\text { Use Attitude }\end{array}$ & Female & 114 & 2.7992 & .39841 & & \\
\cline { 2 - 5 } & Male & 90 & 2.7053 & .30707 & & \\
\hline
\end{tabular}

In Table 8 , it could be observed that there was no significant difference between the attitudes of students towards digital dictionary use based on the gender variable $(t=-1.901, p>0.05)$. It was observed that male students' attitudes towards digital dictionary use were lower than female students. However, this finding revealed that gender had no effect on student attitudes towards digital dictionary use.

\subsection{Analysis of digital dictionary use attitudes based on student grade level}

Table 9. Digital dictionary use attitudes based on student grade level

\begin{tabular}{ccccccc}
\hline & Grade & $\mathrm{N}$ & Mean & $\mathrm{Sd}$ & $\mathrm{F}_{(3,200)}$ & $\mathrm{p}$ \\
\hline \multirow{4}{*}{$\begin{array}{c}\text { Digital } \\
\text { Dictionary Use } \\
\text { Attitude }\end{array}$} & 5th Grade & 52 & 2.6447 & .38023 & & \\
\cline { 2 - 5 } & 6th Grade & 49 & 2.7658 & .37387 & \multirow{2}{*}{3.216} & 0.024 \\
\cline { 2 - 5 } & 7th Grade & 50 & 2.7579 & .30300 & & \\
\cline { 2 - 5 } & 8th Grade & 53 & 2.8610 & .36582 & & \\
\hline
\end{tabular}


In Table 9, it could be observed that the mean attitude score of the students towards digital dictionary use was $X=2.65$ in the 5th grade, $X=2.77$ in the 6th grade, $X=2.76$ in the 7 th grade and $X=2.86$ in the 8th grade. Thus, student attitudes towards digital dictionary use increased with their grade levels. On the other hand, it was determined that there was a significant difference between the mean attitude towards digital dictionary use scores based on the student grade level $(F=3.216, p<0.05)$. This finding demonstrated that the attitudes of the students towards digital dictionary use increased as their class level increased. Hence, it can be suggested that the knowledge and experience acquired by the students on digital dictionary use at middle school level were sufficient to create positive attitudes.

\subsection{Analysis of digital dictionary use attitudes based on the age of initial dictionary use}

Table 10. Digital dictionary use attitudes based on the age of initial dictionary use

\begin{tabular}{ccccccc}
\hline & $\begin{array}{c}\text { Initial Dictionary } \\
\text { Use Age }\end{array}$ & $\mathrm{N}$ & Mean & $\mathrm{Sd}$ & $\mathrm{F}_{(2,201)}$ & $\mathrm{p}$ \\
\hline $\begin{array}{c}\text { Digital } \\
\text { Dictionary Use } \\
\text { Attitude }\end{array}$ & Preschool & 16 & 2.6596 & .41436 & & \\
\cline { 2 - 5 } & Primary School & 158 & 2.7564 & .36811 & 0.908 & 0.405 \\
\cline { 2 - 5 } & Middle School & 30 & 2.8140 & .30619 & & \\
\hline
\end{tabular}

In Table 10, it could be observed that the mean digital dictionary use attitude scores of the students who started to use dictionaries in preschool school was $X=2.65$, that of the students who started to use dictionaries at primary age was $X=2.76$, and that of the students who started to use dictionaries in middle school was $X=2.81$. Thus, it was determined that the initial age of dictionary use did not make a no significant difference in the mean digital dictionary use attitude scores $(F=0.908, p>0.05)$. This finding can be explained by the fact that the children of our age can use digital devices more easily and are more prone to using them. Therefore, the attitudes of children with digital skills to use digital dictionaries also develop over time.

\subsection{Analysis of the correlation between the attitudes towards printed and digital dictionary use}

Table 11. Pearson correlation analysis

\begin{tabular}{rrr}
\hline Attitude & $(1)$ & $(2)$ \\
\hline \multirow{2}{*}{$(1)$ Printed Dictionary } & 1 & $.463^{* *}$ \\
\cline { 2 - 3 } (2) Digital Dictionary & $.463^{* *}$ & $\mathbf{. 0 0 0}$ \\
\cline { 2 - 3 } & $\mathbf{. 0 0 0}$ & 1 \\
\hline
\end{tabular}

In Table 11, the correlation analysis on the relationship between the attitudes of middle school students towards printed and digital dictionary use could be observed. Thus, there was a positive and moderate correlation between student attitudes towards dictionary use $(r=0.463, p<0.00)$. This finding confirmed that as the attitudes of middle school students towards using a printed dictionary increased, their attitudes towards using a digital dictionary increased as well. 


\section{Discussion}

The students should acquire the habit of dictionary use as a lifelong learning skill that they could benefit from not only in school age but throughout their lives. Thus, the family and especially the primary school Turkish language courses share significant responsibility in the acquisition of this skill. However, in order to acquire the dictionary use habit permanently, it is necessary for the student to need and like dictionary use. Therefore, the students' interest and attitude as well as their knowledge on dictionaries and dictionary use are important. To develop a positive attitude towards the dictionaries, the dictionaries should be used in courses in a pleasurable way. Thus, the present study aimed to compare the attitudes of middle school students towards printed and digital dictionary use and to analyze these attitudes based on various factors, and a number of findings were obtained:

It was determined that the attitude of the middle school students towards printed dictionary use was at a good level with a mean score of 2.54 and digital dictionary attitude score 2.76 . This finding demonstrated that middle school students had developed a generally above-average positive attitude for both printed and digital sources towards dictionary use. However, it was also clear that there was a need to improve the attitudes of the students towards printed dictionary use. The high attitudes towards digital or electronic dictionary use was consistent with the findings reported in the literature (Al-Smael, 2000; Alhaysony, 2011). Yaman and Dagtas (2014) investigated the attitudes towards dictionaries based on the dimensions of dictionary use habit and its benefits, and the study findings were consistent with the present study results. Furthermore, in a study by Kardas (2016) the attitudes of learners of Turkish as a foreign language towards dictionaries were analyzed, it was reported that students exhibited aboveaverage attitudes.

It was determined the difference between the attitudes towards printed and digital dictionary use was not significant based on gender. This finding contradicted with the findings reported by Yaman and Dagtas (2014). However, in a study conducted by Kardas (2016) on students who learned Turkish as a foreign language, it was reported that gender variable was not effective on dictionary use attitudes. In fact, in the present study, it was determined that the attitudes of the female students were higher. Also, the present study findings were not consistent with other reading attitude researchs that female students had higher attitude levels (Balc1, 2009; Basaran \& Ates, 2009; Mete, 2012).

It was observed that the attitudes of middle school students towards printed and digital dictionary use increased with their grade level. The lowest attitude towards printed and digital dictionary use was observed in the 6th grade and the highest attitude was observed in the 8th grade. Analysis of the performance of all grade levels demonstrated that the grade level was not a significant factor on printed dictionary use attitudes. On the other hand, it was determined that there was a significant difference between the attitudes towards digital use favoring the $8^{\text {th }}$ grade students. However, contrary to this finding, Yaman and Dagtas (2014) reported that there was a difference favoring the 6th grade students. This finding evidenced that the grade level, and therefore the middle school education had a positive effect on student attitudes towards dictionary use. Similarly, Melanlığlu (2013) reported that the habit of dictionary use improved with the grade level.

It was observed that the age of initial dictionary use made a significant difference in the attitude towards printed dictionary use but not towards digital dictionary use. This finding demonstrated that time was also effective in the development of a positive attitude towards a behavior. Dictionary use is necessary for the achievement of reading and other language skills and turning these skills into habits. Thus, children should develop a love for reading and the habits of reading books and visiting libraries should be acquired at a young age. In fact, Elbir and Bagc1 (2013) emphasized that children should acquire the love of reading and the habit of using libraries at a young age in order to acquire reading habits. Thus, when children acquire the habit of dictionary use in addition to reading books at a young 
age, as the present study findings demonstrated that success would be most likely. However, the finding that the attitude towards digital or electronic dictionary use was high in younger ages and increased with age was important.

It was determined that there was a positive and moderate correlation between the attitudes of middle school students towards printed and digital dictionary use. According to Ozdamar-Keskin et al (2015), participants generally preferred learning with graphics or visuals, listening, and written material. In a study by Oflaz (2019) on the use of mobile and printed dictionaries, and Kaplan and Yildız (2018) on determination student views on electronic dictionaries, it was observed that students preferred using both printed for reasons such as portability, cheapness and practicality and digital dictionaries for reasons such as speed, convenience, more word. These studies explained why students preferred both printed and digital dictionaries in learning vocabulary.

\section{Conclusion}

In conclusion, it was demonstrated that middle school students exhibited positive attitudes towards both printed and digital dictionary use. Furthermore, there was no significant difference between the attitudes towards dictionary use based on gender. Nevertheless, it was determined that female students had higher attitudes in digital dictionary while male students had higher attitudes in printed dictionary usage. As the class level increase, so does the attitude towards using both printed and digital dictionaries. Furthermore, the attitudes towards printed dictionaries of the students who started to use dictionary in primary school and preschool were higher, and the attitudes towards digital dictionary use was higher among the students who started to use dictionaries in middle school.

\subsection{Recommendations}

The present study findings demonstrated that above-average attitude scores of middle school students towards printed and digital dictionary use would not be sufficient for lifetime utilization of this skill. Thus, it could be recommended to allow students to use different types of dictionaries in entertaining activities in the middle school, especially in Turkish language courses, to utilize not only printed but also digital dictionaries in the courses, to provide in-service training to the teachers on dictionary use habits, and to include dictionary use instructions in textbooks and dictionary use principles in the curriculum.

\section{Ethics Committee Approval}

The author(s) confirm(s) that the study does not need ethics committee approval according to the research integrity rules in their country (Date of Confirmation: June 12, 2020).

\section{References}

Ahmed, N., Jawaid, A., Kaur, P. \& Khalid, R. (2018). Dictionary using habits of electrical engineering students in Lahore, Pakistan. Language in India, 18(3), 625-631. Retrieved from http://www.languageinindia.com 
Alhaysony, M. (2011). Dictionary look-up behavior of Saudi female EFL students. European Journal of Social Sciences, 26(2), 250-267. Retrieved from http://www.europeanjournalofsocialsciences.com.

Al-Smael, F. (2000). A think-aloud protocols investigation of lexico-semantic problems and problemsolving strategies among trainee English-Arabic translators (BL). Master thesis. Durham Üniversitesi.

Aslan, E. (2016). A study on the use of mobile dictionaries in vocabulary teaching. Journal of Language and Linguistic Studies, 12(1), 1-8. Retrieved from https://www.jlls.org/index.php/jlls/article/view/463/227

Ayoub, M. T., Mehmood, K. \& Awan, A. G. (2017). A study of dictionary using habits of students at secondary level in the urdu medium schools in district khanewal Pakistan. Global Journal of Management, Social Sciences and Humanities, 3(3), 515-533. Retrieved from https://www.gjmsweb.com.

Balc1, A. (2009). Elementary 8th grade students' attitudes towards reading habits. Mustafa Kemal University Journal of Social Sciences Institute, 6(11), 265-300. Retrieved from https://dergipark.org.tr/tr/download/article-file/183151.

Baskın, S. (2017). 5. sınıf öğrencilerinin sözlük ihtiyacı ve ortaokul sözlükleri. Türkiye Sosyal Araştırmalar Dergisi, 21 (3), 765-789.

Basaran, M. \& Ates, S. (2009). An investigation of fifth graders' attitudes towards reading. Gazi University Journal of Gazi Educational Faculty, 29(1), 73-92. Retrieved from http://www.gefad.gazi.edu.tr/en/download/article-file/77091.

Boz, E. \& Demirtas, A.A. (2011). The attitudies and behaviours of Turkish language teachers towards school dictionary usage. Journal of Language and Literature Research, 3, 65-134.

Can, A. \& Deniz, E. (2016). Attitudes of high school student's towards dictionaries. National Education, 210, 320-336. Retrieved from https://dergipark.org.tr/tr/download/article-file/441277

Cohen, L., Manion, L. \& Morrison, K. (2007). Research methods in education. London: Routledge.

Cowie, A. P. (Ed) (1999). English dictionaries for foreign learners. Oxford: Clarendon Press.

Dagtas, A. (2014). Opinions of secondary school 7th class students directed towards electronic dictionaries. The Journal of Academic Social Science, 2(7),542-555. https://doi.org/http://dx.doi.org/10.16992/ASOS.389

Elbir, B. \& Bagc1, C. (2013). The evaluation of graduate studies on teaching reading in the first and second stage. Adryaman University Journal of Social Sciences Special Issue, 11, 229-247. https://doi.org/10.14520/adyusbd.412

Gocer, A. (2009). Activities of developing vocabulary of students and dictionary usage in Turkish education. Turkish Studies, 4(4), 1025-1055. 10.7827/TurkishStudies.1318

Gomleksiz, M. N. (2004). Validity and reliability of an attitude scale towards reading habit. Firat University Journal of Social Science, 14(2), 185-195. Retrieved from http://web.firat.edu.tr/sosyalbil/dergi/arsiv/cilt14/sayi2/185-196.pdf

Gunbatar, M. S. (2014). The study on development of information and communication technology attitude scale. Ahi Evran University Joumal of Kırşehir Education Faculty, 15(1), 121-135. Retrieved from https://toad.halileksi.net/sites/default/files/pdf/bit-bilgi-ve-iletisim-teknolojileritutum-olcegi-toad.pdf 
Ibe Akcan, P. (2015). The dictionary use of language students at the university level. Hacettepe University Journal of Faculty of Letters, 32(2), 89-104.

Ilhan, N. (2009). The principles, types and features of dictionary making. Turkish Studies 4(4), 534554. http://dx.doi.org/10.7827/TurkishStudies.819

Kaplan, T. \& Yildız, F. (2018). The opinions of middle school 8th graders about electronic dictionary usage. ulakbilge, 6(20), s.101-112. 10.7816/ulakbilge-06-20-06

Karahan, B.U. (2018). Reading attitude scale: A scale development study. Kastamonu Education Journal, 26(1), 67-73. https://doi.org/10.24106/kefdergi.375179

Karal H., Kokoç M., Çolak C. \& Yalçin Y., (2015). A case study on online mathematics teaching with pen-based technology: Experiences of two instructors. Contemporary Educational Technology, 6, 319-337. Retrieved from https://files.eric.ed.gov/fulltext/EJ1105757.pdf

Kardas, D. (2016). A study on attitude and habit of using dictionary by students who learn Turkish as a foreign language. National Education, 210, 507-519. https://dergipark.org.tr/en/download/articlefile/441292

McMillian, J. H. \& Schumacher, S. (2001). Research in education: A conceptual introduction. New York: Longman

Melanlıoğlu, D. (2013). Middle school students' dictionary use habits: A qualitative study. Internation Journal of Turkish, Literature, Culture, Education, 2(2), 266-284. Retrieved from http://www.tekedergisi.com/Makaleler/38201901_14melanl\%C4\%B1o\%C4\%9Flu.pdf

Mete, G. (2012). A research on elementary 8th grade students' reading habits (Malatya sample). Journal of Language and Literature Research, 1(1), 43-66.

Ministry of National Education (2018). Turkish course (1-8. grades) teaching program. Ankara: Ministry of National Education Pub.

Nesi, H. \& Haill, R. (2002) A study of dictionary use by international students at a British University. International Journal of Lexicography, 15(4), 277-305. http://dx.doi.org/10.1093/ij1/15.4.277

Oflaz, A. (2019). Yabancı dil olarak Almanca öğreniminde mobil/çevrimiçi ve basılı sözlük kullanımı. Diyalog 1, 125-139. Retrieved from https://dergipark.org.tr/tr/download/article-file/755493

Ozbay, M. \& Melanlıglu, D. (2013) An investigation into skills of foreigner Turkish learners' dictionary use. Journal of Mother Tongue Education, 1(1), 13-23. Doi.10.16916/aded.16015

Ozdamar-Keskin, N., Ozata, F. Z., Banar, K. \& Royle, K. (2015). Examining digital literacy competences and learning habits of open and distance learners. Contemporary Educational Technology, 6(1), 74-90. Retrieved from https://eric.ed.gov/?id=EJ1105611

Turkish Language Institution (2011). Turkish dictionary. Ankara: TDK Pub.

Yaman, H. (2010). On the evaluation of the primary education second level students' dictionary use habits. Journal of Turkology Research, 27, 735-751. Retrieved from https://dergipark.org.tr/en/download/article-file/157017

Yaman, H. \& Dagtas, A. (2013). Dictionary oriented attitude scale: validity and reliability study. Mustafa Kemal University Journal of Social Sciences Institute, 10(24), 15-27. Retrieved from https://dergipark.org.tr/tr/download/article-file/182944

Yaman, H. \& Dagtas, A. (2014). Attitudes of secondary school $6^{\text {th }}, 7^{\text {th }}$ and $8^{\text {th }}$ class students towards dictionarıes: a descriptive analysis. Turkish Studies, 9(3), 1581-1597. 10.7827/TurkishStudies.6356 
URL-1 https://sozluk.gov.tr/

URL-2 https://www.oxfordlearnersdictionaries.com/

URL-3 http://global.longmandictionaries.com/

URL-4 https://dictionary.cambridge.org/dictionary/english/

\section{Basılı ve dijital sözlük kullanmaya yönelik öğrenci tutumlarının karşılaştırılması: ortaokul örneği}

\section{$\ddot{O} \mathbf{z}$}

Araştırmada, ortaokul öğrencilerinin basılı ve dijital sözlük kullanmaya yönelik tutumlarının karşılaştırılması amaçlanmıştır. Araştırma, var olan bir durumu belirlenmeyi amaçladığı için tarama modeline göre yürütülmüştür. Araştırmanın evrenini 2018-2019 öğretim yılında, Giresun il merkezinde öğrenim gören ortaokul öğrencileri oluşturmaktadır. Araştırma evrenini temsil edecek özellikte örneklem ise tesadüfi örnekleme yöntemi ile il merkezindeki bir ortaokulda öğrenim gören öğrenciler arasından rastgele $(n=204)$ seçilmiştir. Araştırmanın verileri, bilgi formu ve tutum ölçekleri ile toplanmıştır. Araştırma sonucunda, öğrencilerin basılı sözlük $(X=2,54$ /4) ve dijital sözlük kullanımına ( $X=2,76$ / 4) yönelik genel olarak İyi düzeyde tutuma sahip olduğu tespit edilmiştir. Bununla beraber cinsiyetin sözlük kullanmaya yönelik tutum üzerinde anlamlı bir etkisinin olmadığı belirlenmiştir. Sınıf düzeyi yükseldikçe sözlük kullanmaya yönelik tutumun da yükseldiği, ilkokul ve öncesinde sözlük kullanmaya başlayan öğrencilerin tutumlarının diğerlerinden daha iyi olduğu ulaşılan önemli sonuçlardandır.

Anahtar Sözcükler: Sözlük; basıl1; dijital; sözcük hazinesi; kullanma; tutum.

\section{AUTHOR BIODATA}

Aslı Maden is working as a lecturer in the department of Turkish Language at Giresun University. Turkish Language Education Department and received his Ph.D. His research areas include electronic dictionary, vocabulary, digital reading and writing skills, language skills and Turkish teaching as a foreign language. 